\title{
Effects of an LHRH antagonist on gonadotrophin and oestradiol secretion, follicular development, oestrus and ovulation in Holstein heifers
}

\author{
D. Rieger* $\S$, S. Roberge*ף, D. H. Coy† and N. C. Rawlings $\ddagger$ \\ * Centre de recherche en reproduction animale, Faculté de médecine vétérinaire, Université de \\ Montréal, C.P. 5000, St-Hyacinthe, Québec, Canada J2S 7C6; †Department of Medicine, Tulane \\ University School of Medicine, 1430 Tulane Avenue, New Orleans, LA 70112, USA; and \\ ¥Department of Veterinary Physiological Sciences, Western College of Veterinary Medicine, \\ University of Saskatchewan, Saskatoon, Saskatchewan, Canada S7N OWO
}

\begin{abstract}
Summary. Mature cyclic Holstein heifers were given a luteolytic dose of cloprostenol followed by two i.v. injections, $12 \mathrm{~h}$ apart, of various doses of [Ac-D-Nal ${ }^{1}, \mathrm{D}-\mathrm{p}-\mathrm{Cl}-\mathrm{Phe}{ }^{2}$, D-Trp ${ }^{3}, \mathrm{D}-\mathrm{Arg}^{6}, \mathrm{D}-\mathrm{Ala}^{10}$ ]-LHRH, beginning either at the time of first observation of behavioural oestrus, or $48 \mathrm{~h}$ after the cloprostenol injection. When treatment began at the first observation of oestrus, the time of ovulation, as determined by ultrasonic echography, was significantly delayed by total doses of $0.8 \mathrm{mg}$ or more of the antagonist. When given at 48 and $60 \mathrm{~h}$ after cloprostenol injection, a total dose of $1.5 \mathrm{mg}$ of the antagonist significantly delayed the growth of the ovulating follicle, the onset of oestrus, the preovulatory surges of oestradiol, $\mathrm{LH}$ and FSH, and ovulation. It is concluded that the LHRH antagonist can effectively suppress endogenous LH secretion and may therefore be useful in the study of follicular development, ovulation, and other events in the oestrous cycle of the cow.
\end{abstract}

Keywords: LHRH; antagonist; heifer; oestrus; ovulation

\section{Introduction}

Several antagonistic analogues of luteinizing hormone-releasing hormone (LHRH) have been shown to suppress endogenous LH secretion and to inhibit ovulation in the rat and primates (see Nekola \& Coy, 1984). The results of a limited number of studies in domestic animals suggest that LHRH antagonists can inhibit LH secretion in rams (Lincoln \& Fraser, 1987), fetal lambs (Matwijiw \& Faiman, 1986), and cyclic mares (E. Palmer, personal communication). However, aside from our brief report (Roberge et al., 1987) of the results presented here, there is, to our knowledge, no information available about the effects of LHRH antagonists in cattle.

Two dose-response experiments were performed to determine whether [Ac-D-Nal ${ }^{1}, \mathrm{D}-\mathrm{p}-\mathrm{Cl}$ $\left.\mathrm{Phe}^{2}, \mathrm{D}-\mathrm{Trp}^{3}, \mathrm{D}-\mathrm{Arg}^{6}, \mathrm{D}-\mathrm{Ala}{ }^{10}\right]-\mathrm{LHRH}$, a potent antagonist of LHRH, given during the follicular phase of the oestrous cycle in mature Holstein heifers could suppress endogenous gonadotrophin secretion and thus delay the preovulatory $\mathrm{LH}$ surge and ovulation.

\$̧Present address: Department of Biomedical Sciences, Ontario Veterinary College, University of Guelph, Guelph, Ontario, Canada N1G 2W 1 .

- Present address: Department of Animal Sciences, Washington State University, Pullman, WA 99164-6332, USA. 


\section{Materials and Methods}

Animals. Mature, normally cyclic Holstein heifers were kept in a heated barn, fed hay and grain, allowed water ad libitum, and monitored twice daily for oestrous behaviour. The day of first detected oestrous behaviour was defined as Day 0 of the cycle. For the experiments, animals were selected at random from the experimental herd, and given a single i.m. injection of $0.5 \mathrm{mg}$ cloprostenol (Estrumate: ICI Pharma, Mississauga, Ontario, Canada) between Days 6 and 15 of the cycle to induce luteolysis.

LHRH antagonist. The LHRH antagonist $\left[\mathrm{Ac}-\mathrm{D}-\mathrm{Nal}{ }^{1}, \mathrm{D}-\mathrm{p}-\mathrm{Cl}-\mathrm{Phe}^{2}, \mathrm{D}-\mathrm{Trp}^{3}, \mathrm{D}-\mathrm{Arg}^{6}, \mathrm{D}-\mathrm{Ala}^{10}{ }^{10}-\mathrm{LHRH}\right.$ was synthesized by D. H. Coy using solid-phase methods, as previously described (Erchegyi et al., 1981).

Experiment I. After cloprostenol treatment, each heifer received a total dose of $0(\mathrm{~N}=3), 0 \cdot 4(\mathrm{~N}=3), 0 \cdot 8(\mathrm{~N}=4)$ or $1.6(\mathrm{~N}=3) \mathrm{mg}$ of the LHRH antagonist in two i.v. injections of $0.5 \mathrm{ml}$ of $0.154 \mathrm{M}-\mathrm{NaCl}$ given at, and $12 \mathrm{~h}$ after, the first observation of oestrous behaviour. Beginning $24 \mathrm{~h}$ after cloprostenol injection, ovarian follicular development was monitored transrectally, twice daily by real-time ultrasonic echography, using a linear array scanner equipped with a $5 \mathrm{MHz}$ probe (Equisonics Inc, Elk Grove, IL, USA). The time of ovulation was defined as being when an identifiable corpus haemorrhagicum was first observed.

Experiment II. Each heifer received a total dose of $0(\mathrm{~N}=6), 0 \cdot 5(\mathrm{~N}=3), 1 \cdot 0(\mathrm{~N}=3)$ or $1 \cdot 5(\mathrm{~N}=3) \mathrm{mg}$ of the LHRH antagonist in two i.v. injections of $0.5 \mathrm{ml} 0.154 \mathrm{M}-\mathrm{NaCl}$ given at 48 and $60 \mathrm{~h}$ after cloprostenol injection. Ovarian follicular development was monitored as described above, beginning $24 \mathrm{~h}$ before cloprostenol injection. Indwelling jugular catheters were implanted on the day after cloprostenol treatment and $10 \mathrm{ml}$ blood samples were taken hourly from the time of the first injection of saline or LHRH antagonist until ovulation. The serum was kept frozen at $-20^{\circ} \mathrm{C}$ until assayed for oestradiol, progesterone, LH and FSH content.

Hormone assays. The serum concentrations of oestradiol and progesterone were measured as previously described (Guay et al., 1988), in the samples taken at $0,24,48 \mathrm{~h}$ and every $12 \mathrm{~h}$ from 54 to $114 \mathrm{~h}$ after cloprostenol injection. For the assay of progesterone, the sensitivity, and intra- and inter-assay coefficients of variation were $62.5 \mathrm{pg} / \mathrm{ml}, 11.5 \%$ and $10.4 \%$, respectively. For the assay of oestradiol, the sensitivity, and intra- and inter-assay coefficients of variation were $2 \mathrm{pg} / \mathrm{ml}, 10 \cdot 6 \%$ and $6 \cdot 2 \%$, respectively.

The concentrations of LH were measured in duplicate samples of $200 \mu 1$ serum, exactly as previously described (Kennedy \& Rawlings, 1984). The sensitivity, and intra- and inter-assay coefficients of variation were $62.5 \mathrm{pg} / \mathrm{ml}$, $9 \cdot 1 \%$ and $10 \cdot 8 \%$, respectively.

Serum FSH concentrations were measured in duplicate samples of $200 \mu 1$ serum in a heterologous radioimmunoassay using ${ }^{125}$ l-labelled sheep FSH (NIAMDD-oFSH-I-1), an antiserum raised against ovine FSH (NIAMDD anti-oFSH-1) at a final dilution of 1:80000, and a standard curve of bovine FSH (USDA-bFSH-B1) varying from $2-240 \mathrm{ng} / \mathrm{ml}$. The labelling and other assay procedures were exactly as previously reported (Kennedy \& Rawlings, 1984). The cross-reaction of the assay was $3 \cdot 27 \%$ for LH (NIAMDD-bLH-4), and $<1 \%$ for TSH (NIHTSH-B5), growth hormone (NIH-GH-B17) and prolactin (NIH-PR-B3). The concentration of FSH in serum from an ovariectomized cow was measured as $120 \mathrm{ng} / \mathrm{ml}$. The sensitivity, and intra- and inter-assay coefficients of variation were $2 \mathrm{ng} / \mathrm{ml}, 6 \cdot 3 \%$ and $7 \cdot 7 \%$, respectively.

Statistical analyses. All inter-group comparisons were made using the Mann-Whitney U test (Guilford \& Fruchter, 1973).

\section{Results}

The effects of the LHRH antagonist on the preovulatory intervals in Exp. I are summarized in Fig. 1. The interval from cloprostenol injection to oestrus (the time of first injection of antagonist) was not different among the four treatment groups, indicating that they were functionally equivalent at the time of initiation of treatment.

Following antagonist treatment, all animals, except 2 in the $0.8 \mathrm{mg}$ group, ovulated spontaneously. The overall mean ( \pm s.d.) maximum antral diameter of the spontaneously ovulating follicles was $15.4 \pm 2.7 \mathrm{~mm}$, and did not differ among treatment groups. The follicular development in the 2 animals that did not ovulate spontaneously was monitored for 13 days after cloprostenol treatment (Fig. 2), at which time they were given 1500 i.u. hCG (A.P.L., Ayerst Laboratories, Montréal, Québec, Canada) i.v. Both animals ovulated within $48 \mathrm{~h}$ of hCG treatment.

The interval from onset of oestrus (the time of first antagonist treatment) to ovulation was significantly longer in the 0.8 and $1.6 \mathrm{mg}$ groups than the control group, reaching a mean delay of 


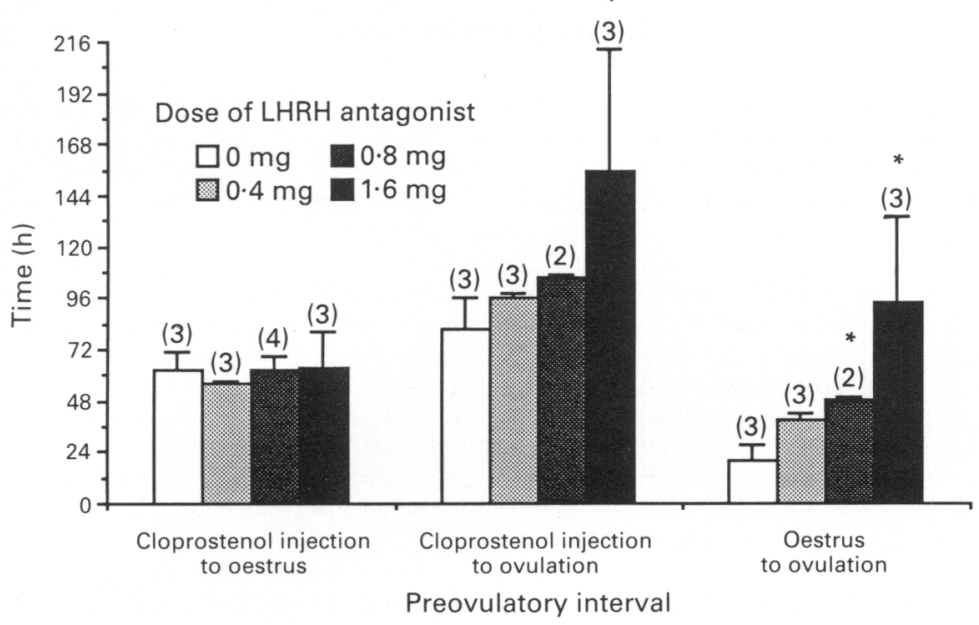

Fig. 1. The times (mean \pm s.d.) from cloprostenol injection to oestrus in Holstein heifers and the effect of LHRH antagonist given as split doses at, and $12 \mathrm{~h}$ after, oestrus on the intervals from cloprostenol treatment to ovulation, and antagonist treatment to ovulation (Exp. I). The numbers of animals are indicated in parentheses. The intervals to ovulation for the $0.8 \mathrm{mg}$ group represent the means for the 2 animals that ovulated spontaneously, but the statistical analyses included the data for all 4 animals in the group. ${ }^{*} \mathrm{P} \leqslant 0.05$ compared with the control group.

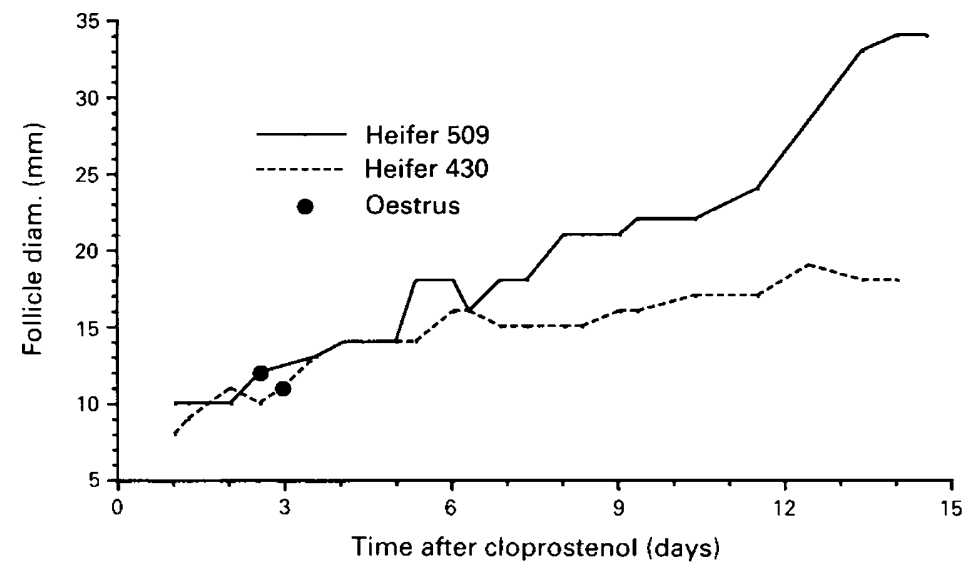

Fig. 2. The growth of the largest follicle in 2 Holstein heifers which received a total dose of $0.8 \mathrm{mg} \mathrm{LHRH}$ antagonist as a split dose at, and $12 \mathrm{~h}$ after, the onset of oestrus, and did not ovulate spontaneously in Exp. I.

$74 \mathrm{~h}$ in the $1.6 \mathrm{mg}$ group. For the purposes of the statistical analysis, the time of ovulation in the 2 animals which did not ovulate spontaneously was taken to be infinity.

In Exp. II, all the animals ovulated spontaneously. The overall mean maximum antral diameter of the ovulating follicles was $15.4 \pm 1.2 \mathrm{~mm}$ and did not differ among treatment groups. However, the time required for the ovulating follicles to reach their maximum antral diameter, relative to the time of cloprostenol injection (Fig. 3), was significantly longer in the $1.5 \mathrm{mg}$ group (115 $\pm 32 \mathrm{~h}$ ) than in the control group $(71 \pm 30 \mathrm{~h})$. 


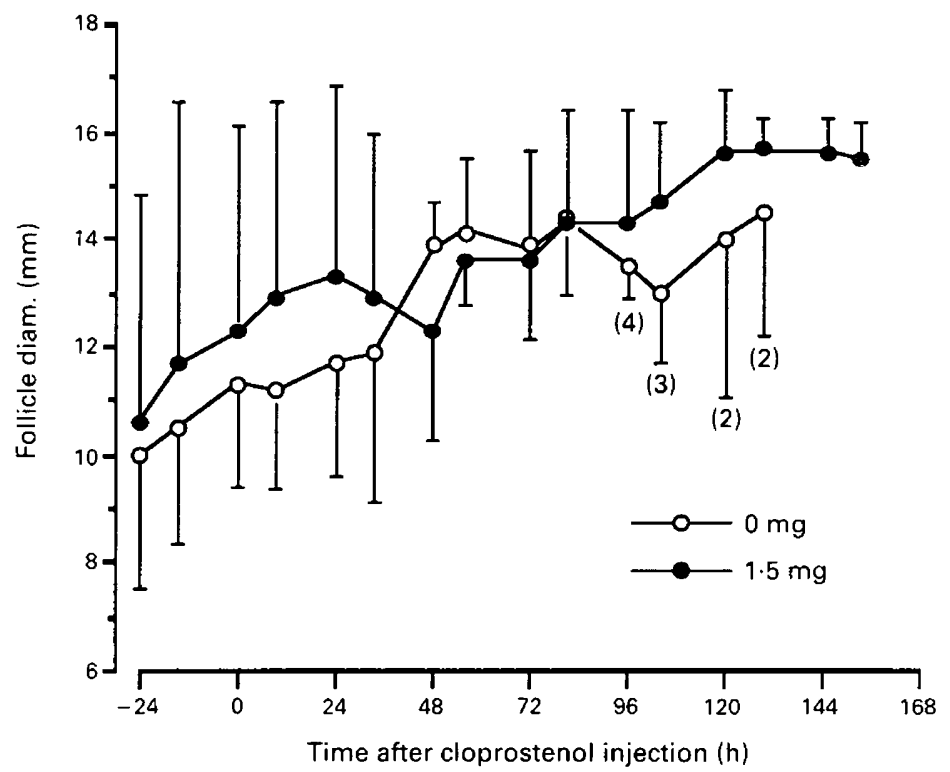

Fig. 3. Mean antral diameter $( \pm$ s.d.) of ovulatory follicles in heifers given $0(\mathrm{~N}=6)$ or $1.5 \mathrm{mg}$ $(\mathrm{N}=3)$ of LHRH antagonist at 48 and $60 \mathrm{~h}$ after injection of cloprostenol (Exp. II). Ovulation was first detected in the $0 \mathrm{mg}$ group at $96 \mathrm{~h}$ and the means for $96-129 \mathrm{~h}$ are for the animals which had not ovulated (numbers in parentheses).

The serum concentration of progesterone fell to $<1 \mathrm{ng} / \mathrm{ml}$ in all animals within $24 \mathrm{~h}$ of cloprostenol treatment and was not different among the treatment groups throughout the sampling period.

As shown in Fig. 4, the times of occurrence of oestrus, the peak serum concentrations of oestradiol, LH and FSH, and ovulation were all significantly delayed in the group treated with $1.5 \mathrm{mg}$ antagonist, compared with the control group. However, when the period from antagonist treatment to ovulation was subdivided into the periods from treatment to peak serum oestradiol concentration, peak oestradiol to peak LH, and peak LH to ovulation (Fig. 5), only the interval from the antagonist treatment to the time of the peak serum concentration of oestradiol was significantly longer for the $1.5 \mathrm{mg}$ group $(70 \cdot 0 \pm 6.9 \mathrm{~h})$ compared to the control group $(18 \cdot 0 \pm 13 \cdot 2 \mathrm{~h})$. The antagonist had no effect on either the interval from peak serum oestradiol to peak serum $\mathrm{LH}$, or the interval from peak serum LH to ovulation.

The effects of the LHRH antagonist on the serum concentrations of oestradiol, LH and FSH are shown in Table 1 . The basal serum concentration of $\mathrm{LH}$, taken as the mean concentration from 1 to $4 \mathrm{~h}$ after the first injection of saline or antagonist, and the peak oestradiol concentration, were significantly reduced in the $1.5 \mathrm{mg}$ group, compared with the control group. The peak serum concentration of $\mathrm{LH}$ was reduced in the $0.5 \mathrm{mg}$ group and significantly reduced in the $1.0 \mathrm{mg}$ group, but was not different in the $1.5 \mathrm{mg}$ group, compared with the control group. The basal concentrations of FSH were below the sensitivity of the assay in all animals, and there was no significant effect of the antagonist on the peak concentrations of FSH.

\section{Discussion}

The times of LHRH antagonist treatment used in this study were chosen to determine its effects on the onset of the preovulatory LH surge, and on preceding follicular development, approximately $24 \mathrm{~h}$ earlier. For Exp. I it was assumed that the onset of the preovulatory LH surge would be 
Dose of LHRH antagonist

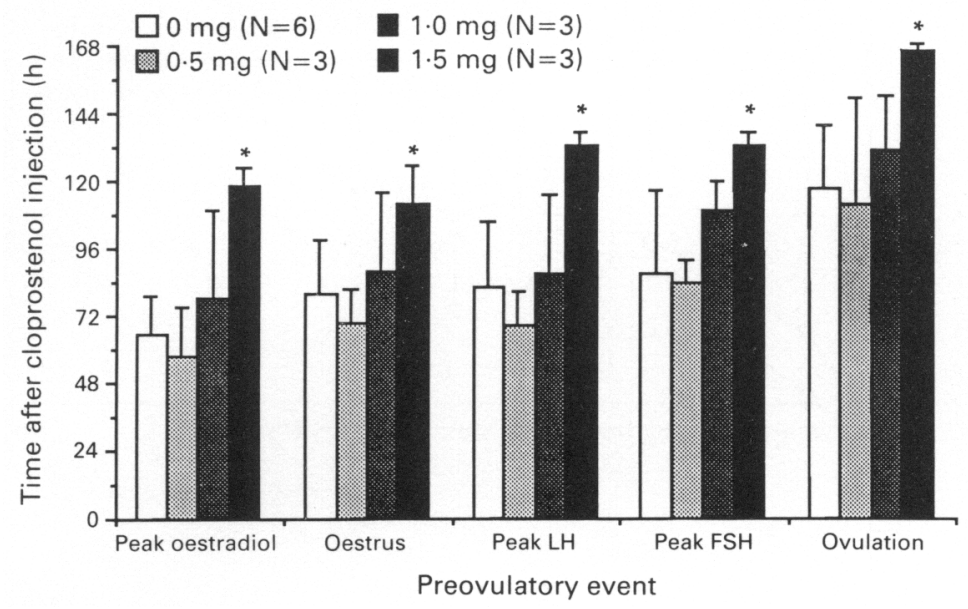

Fig. 4. The effect of various doses of LHRH antagonist, given to Holstein heifers as split doses at 48 and $60 \mathrm{~h}$ after injection of cloprostenol, on the time of occurrence (mean \pm s.d.) of oestrus, the peak serum concentrations of oestradiol, LH and FSH, and ovulation (Exp. II). $* P \leqslant 0.05$ compared with the control group.

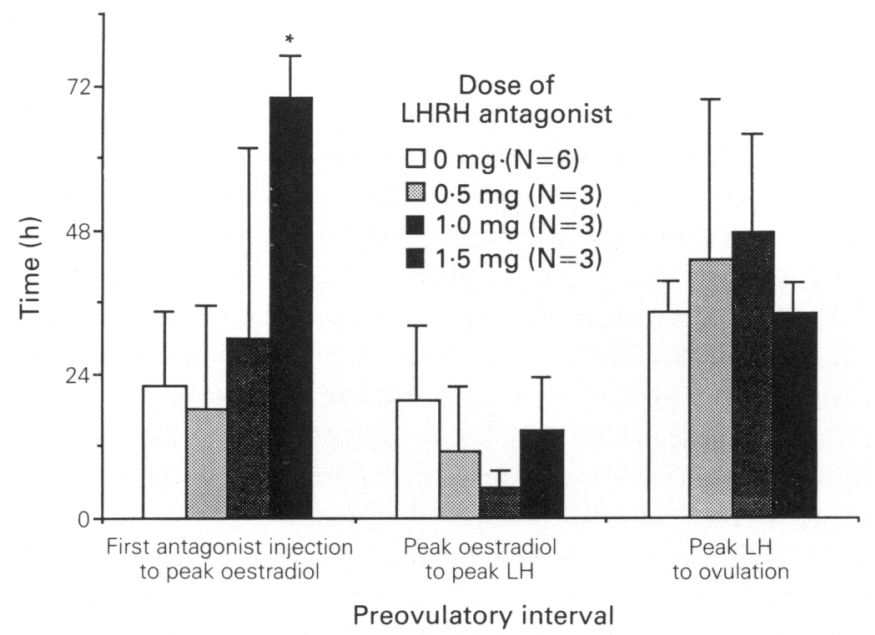

Fig. 5. The effect of various doses of LHRH antagonist given to Holstein heifers as split doses at 48 and $60 \mathrm{~h}$ after injection of cloprostenol, on the intervals (mean \pm s.d.) from first antagonist injection to peak serum oestradiol concentration, from peak oestradiol to peak LH, and from peak $\mathrm{LH}$ to ovulation (Exp. II). ${ }^{*} \mathrm{P} \leqslant 0.05$ compared with the control group.

approximately coincident with the onset of behavioural oestrus, with the peak of the surge occurring within $8 \mathrm{~h}$ thereafter. Although the LH surge does not always follow the onset of oestrus, it usually does (Lucy \& Stevenson, 1986; and 5 of 6 animals in the control group of Exp. II). Therefore treatment with an LHRH antagonist at the onset of oestrus could be expected to exert an effect on the preovulatory LH surge in the majority of animals, but would have no effect on the final stages of follicular growth, which occur before oestrus (Quirk et al., 1986). 
Table 1. The effect of dose of LHRH antagonist in Holstein heifers given at 48 and $60 \mathrm{~h}$ after cloprostenol injection on serum concentrations (mean \pm s.d.) of oestradiol, LH and FSH

\begin{tabular}{|c|c|c|c|c|}
\hline \multirow[b]{2}{*}{ Measure } & \multicolumn{4}{|c|}{ Total dose of LHRH antagonist (mg) } \\
\hline & $\begin{array}{c}0 \\
(\mathrm{~N}=6)\end{array}$ & $\begin{array}{c}0.5 \\
(\mathrm{~N}=3)\end{array}$ & $\begin{array}{c}1 \cdot 0 \\
(\mathrm{~N}=3)\end{array}$ & $\begin{array}{c}1.5 \\
(\mathrm{~N}=3)\end{array}$ \\
\hline Peak serum oestradiol $(\mathrm{pg} / \mathrm{ml})$ & $29 \cdot 9 \pm 8.5$ & $26 \cdot 3 \pm 8 \cdot 6$ & $24 \cdot 9 \pm 10 \cdot 6$ & $19 \cdot 7 \pm 2 \cdot 6^{*}$ \\
\hline Basal serum LH (ng/ml) & $0.40 \pm 0.09$ & $0.43 \pm 0.25$ & $0.27 \pm 0.11$ & $0.25 \pm 0.02 *$ \\
\hline Peak serum $\mathrm{LH}(\mathrm{ng} / \mathrm{ml})$ & $8 \cdot 2 \pm 4 \cdot 2$ & $5 \cdot 5 \pm 4 \cdot 2$ & $2 \cdot 7 \pm 2 \cdot 2^{*}$ & $8.2 \pm 4.7$ \\
\hline Peak serum FSH $(\mathrm{ng} / \mathrm{ml})$ & $21.9 \pm 11 \cdot 5$ & $12 \cdot 8 \pm 4 \cdot 0$ & $19 \cdot 2 \pm 12 \cdot 0$ & $21 \cdot 3 \pm 12 \cdot 9$ \\
\hline
\end{tabular}

${ }^{*} P \leqslant 0.05$ compared with the control $(0 \mathrm{mg})$ group by the Mann-Whitney $\mathrm{U}$ test.

The results of Exp. I clearly demonstrate that treatment with the LHRH antagonist at the onset of oestrus significantly delayed or inhibited spontaneous ovulation. Although LHRH antagonists have been shown to have a direct inhibitory effect on the ovary of the rat (Nekola \& Coy, 1985), and LHRH-like proteins have been identified in bovine granulosa cells (Ireland et al., 1988), Brown \& Reeves (1983) found no indication of LHRH receptors on the ovary of cattle. Therefore, it is most likely that the effect of the antagonist in Exp. I was due to an effect on the pituitary, inhibiting the preovulatory LH surge.

The 2 animals in which spontaneous ovulation was completely blocked may be of special interest because, although we did not collect blood samples or monitor behaviour in these animals, the continued growth of the largest follicles resembled that of cystic follicles. Ovarian follicular cysts are a significant problem in cattle (see Eyestone \& Ax, 1984; De Silva \& Reeves, 1988), and LHRH antagonists could possibly be used to develop a model for studying this syndrome.

In Exp. II, the LHRH antagonist was administered 1 day before the expected time of the onset of oestrus, in order to determine its effects on basal gonadotrophin secretion, and follicular development and function. In this case, the highest dose $(1.5 \mathrm{mg})$ of the antagonist significantly depressed basal LH secretion, and delayed final follicular growth, oestradiol secretion, oestrus, the preovulatory LH and FSH surges, and ovulation. However, the delay of occurrence of the gonadotrophin surges was apparently a secondary effect resulting from the delay in follicular development and oestradiol secretion, presumably due to the suppression of basal LH secretion. The intervals from peak oestradiol concentration to the LH surge, and from the LH surge to ovulation were not different among the groups, indicating that the antagonist had no direct effect on the response of the hypothalamo-pituitary axis to the oestradiol surge or on the response of the ovary to the LH surge.

Two approaches have been used to interrupt the trophic effect of endogenous LHRH secretion on the pituitary and thereby suppress endogenous gonadotrophin secretion in female domestic animals. Active immunization against LHRH has been shown to inhibit gonadotrophin secretion and ovarian function in the gilt (Esbenshade \& Britt, 1985), ewe (McNeilly et al., 1986), mare (Garza et al., 1986), and heifer (Johnson et al., 1988). Alternatively, gonadotrophin secretion and ovulation have been suppressed in the ewe by down-regulation of pituitary LHRH receptors with chronic daily injection (Dobson, 1985) or continuous infusion (McNeilly \& Fraser, 1987) of LHRH agonists.

McNeilly \& Fraser (1987) used a continuous infusion of $50 \mu \mathrm{g}$ buserelin/day from an osmotic minipump implanted s.c. into luteal-phase ewes. They suggest that this approach is superior to that of daily injections of LHRH agonist, which leads to a rise is gonadotrophin concentrations at each injection, and to immunization against $\mathrm{LHRH}$, which produces a less uniform suppression of $\mathrm{LH}$ and FSH secretion. However, in their study, plasma concentrations of LH increased 3-8-fold in the 
first 5 days of infusion before becoming basal, suggesting that this approach may not be applicable when rapid suppression of gonadotrophin secretion is required.

Our results indicate that i.v. treatment with the LHRH antagonist results in a rapid depression of serum $\mathrm{LH}$ concentrations within $4 \mathrm{~h}$ of treatment in the follicular-phase heifer, and therefore, at least in this situation, can be used to study the acute effects of suppression of LH secretion. Furthermore, the protocol used (two i.v. injections, $12 \mathrm{~h}$ apart) is technically very simple, while still having a delaying effect of 2 or more days. However, we did not examine the effects of the antagonist during the luteal phase, and we could not determine the duration of the suppression of basal $\mathrm{LH}$ secretion because of the early onset of the preovulatory surge in the control animals. Consequently, we cannot directly compare our results with those of McNeilly \& Fraser (1987).

In conclusion, we have shown that the LHRH antagonist can suppress the secretion of LH in the follicular-phase heifer, and thus delay follicular development, the onset of the preovulatory surges of oestradiol, LH and FSH, and ovulation. Many aspects of ovarian function can be controlled or modified with hormone treatments; the luteal phase can be shortened by treatment with prostaglandins or artificially extended with progesterone (see Hansel \& Convey, 1983), superovulation can be induced with exogenous gonadotrophins (see Moor et al., 1984), and the timing of the preovulatory LH surge (Fernández-Limia et al., 1977) and ovulation (Cumming et al., 1977) can be advanced with LHRH or its agonists. However, to define the role of gonadotrophins in the control of ovarian function more clearly, their endogenous secretion must be suppressed. We believe that LHRH antagonists can be used to satisfy this requirement and thus could add much to the study of ovarian function in the cow.

In practical application, the ability to delay ovulation may be advantageous in the superovulation of cattle, because such treatment results in a considerable incidence of premature ovulation (Callesen et al., 1987) of immature oocytes (Hyttel et al., 1988), with a reduced ability to be fertilized. Callesen et al. (1987) state that "Any possible measure should be taken to prevent this condition to improve the quality of oocytes ...", and the use of LHRH antagonists may be just such a measure.

We thank the United States National Hormone and Pituitary Program and National Institute of Diabetes and Digestive and Kidney Diseases for antisera and purified hormones used in the gonadotrophin assays; Dr Alan K. Goff for the antisera used in the steroid hormone assays; Dr P. E. H. Diop for help with the ultrasonic echography; and Dr Keith J. Betteridge for critique of the manuscript. Financial support for this work was provided by the Natural Sciences and Engineering Research Council of Canada and le Ministère de l'enseignement supérieur, de la science et de la technologie du Québec.

\section{References}

Brown, J.L. \& Reeves, J.J. (1983) Absence of specific luteinizing hormone releasing hormone receptors in ovine, bovine and porcine ovaries. Biol. Reprod. 29, 1179-1182.

Callesen, H., Greve, T. \& Hyttel, P. (1987) Premature ovulations in superovulated cattle. Theriogenology 28, 155-166.

Cumming, I.A., Baxter, R.W., White, M.B., McPhee, S.R. \& Sullivan, A.P. (1977) Time of ovulation in cattle following treatment with a prostaglandin analogue $(\mathrm{PG}), \mathrm{PG}$ with $\mathrm{LH}-\mathrm{RH}$, or intravaginal silastic coils impregnated with progesterone (PRID). Theriogenology 8, 184, Abstr.

De Silva, M. \& Reeves, J.J. (1988) Hypothalamicpituitary function in chronically cystic and regularly cycling dairy cows. Biol. Reprod. 38, 264-269.
Dobson, H. (1985) Effects of chronic treatment with a GnRH agonist on oestrous behaviour and on the secretion of $\mathrm{LH}$ and progesterone in the ewe. Theriogenology 24, 1-11.

Erchegyi, J., Coy, D.H., Nekola, M.V., Coy, E.J., Schally, A.V., Mezo, I. \& Teplan, I. (1981) Luteinizing hormone-releasing hormone analogs with increased anti-ovulatory activity. Biochem. Biophys. Res. Commun. 100, 915-920.

Esbenshade, K.L. \& Britt, J.H. (1985) Active immunization of gilts against gonadotropin-releasing hormone: effects on secretion of gonadotropins, reproductive function and responses to agonists or gonadotropinreleasing hormone. Biol. Reprod. 33, 569-577.

Eyestone, W.H. \& Ax, R.L. (1984) A review of ovarian follicular cysts in the cow with comparisons to the 
condition in women, rats, and rabbits. Theriogenology 22, 109-125.

Fernández-Limia, O., Murphy, B.D. \& Manns, J.G. (1977) Synchronization of preovulatory LH surges after PGF ${ }_{2 \alpha}$ in beef cattle: the effects of D-Ala-GnRH and testosterone benzoate. Theriogenology 7, 73-79.

Garza, F., Jr, Thompson, D.L. Jr, French, D.D., Wiest, J.J., St George, R.L., Ashley, K.B., Jones, L.S., Mitchell, P.S. \& McNeill, D.R. (1986) Active immunization of intact mares against gonadotropinreleasing hormone: differential effects on secretion of luteinizing hormone and follicle-stimulating hormone. Biol. Reprod. 35, 347-352.

Guay, P., Rieger, D. \& Roberge, S. (1988) Superovulatory and endocrine responses in Holstein heifers treated with either prostaglandin F2 $\alpha$, cloprostenol, or fenprostalene. Theriogenology 29, 1193-1200.

Guilford, J.P. \& Fruchter, B. (1973) Fundamental Statistics in Psychology and Education, pp. 220-225. McGraw-Hill, New York.

Hansel, W. \& Convey, E.M. (1983) Physiology of the estrous cycle. J. Anim. Sci. 57 (Suppl. 2), 404423.

Hyttel, P., Greve, T. \& Callesen, H. (1988) Ultrastructure of in-vivo fertilization in superovulated cattle. $J$. Reprod. Fert. 82, 1-13.

Ireland, J.J., Aten, R.F. \& Behrman, H.R. (1988) GnRHlike proteins in cows: concentrations during corpora lutea development and selective localization in granulosal cells. Biol. Reprod. 38, 544-550.

Johnson, H.E., DeAvila, D.M., Chang, C.F. \& Reeves, J.J. (1988) Active immunization of heifers against luteinizing hormone-releasing hormone, human chorionic gonadotrophin and bovine luteinizing hormone. J. Anim. Sci. 66, 719-726.

Kennedy, R.I. \& Rawlings, N.C. (1984) Administration of constant low doses of androgens to steers by silastic implant. $J$. Androl. 5, 87-92.

Lincoln, G.A. \& Fraser, H.M. (1987) Compensatory response of the luteinizing-hormone-releasinghormone ( $\mathrm{LHRH}) / \mathrm{LH}$ pulse generator after administration of a potent LHRH antagonist in the ram. Endocrinology 120, 2245-2250.
Lucy, M.C. \& Stevenson, J.S. (1986) Gonadotropinreleasing hormone at estrus: luteinizing hormone, estradiol, and progesterone during the periestrual and postinsemination periods in dairy cattle. Biol. Reprod. 35, 300-311.

Matwijiw, I. \& Faiman, C. (1986) Effect of a specific gonadotropin-releasing hormone antagonist upon pulsatile LH secretion in the ovine fetus. Clin. Res. 34, 909A, Abstr.

McNeilly, A.S. \& Fraser, H.M. (1987) Effect of gonadotrophin-releasing hormone agonist-induced suppression of LH and FSH on follicle growth and corpus luteum function in the ewe. $J$. Endocr. 115, 273-282.

McNeilly, A.S., Jonassen, J.A. \& Fraser, H.M. (1986) Suppression of follicular development after chronic LHRH immunoneutralization in the ewe. $J$. Reprod. Fert. 76, 481-490.

Moor, R.M., Kruip, Th.A.M. \& Green, D. (1984) Intraovarian control of folliculogenesis: limits to superovulation? Theriogenology 21, 103-116.

Nekola, M.V. \& Coy, D.H. (1984) LHRH antagonists in females. In LHRH and Its Analogues: $A$ New Class of Contraceptive and Therapeutic Agents, pp. 125-136. Eds B. H. Vickery, J. J. Nestor \& E. S. E. Hafez. MTP Press, Boston.

Nekola, M.V. \& Coy, D.H. (1985) Direct and indirect inhibition of ovulation in rats by an antagonist of luteinizing hormone-releasing hormone. Endocrinology 116, 756-760.

Quirk, S.M., Hickey, G.J. \& Fortune, J.E. (1986) Growth and regression of ovarian follicles during the follicular phase of the oestrous cycle in heifers undergoing spontaneous and PGF-2 $\alpha$-induced luteolysis. J. Reprod. Fert. 77, 211-219.

Roberge, S., Rieger, D., Coy, D.H. \& Cook, S.J. (1987) LHRH-antagonist induced delay of estrus, the LH surge, and ovulation in Holstein heifers. Biol. Reprod. 36 (Suppl. 1), 118, Abstr. 